\title{
Protective effect of testosterone on early apoptotic damage induced by streptozotocin in rat pancreas
}

\author{
S Morimoto ${ }^{1}$, C A Mendoza-Rodríguez ${ }^{2}$, M Hiriart $^{3}$, \\ M E Larrieta ${ }^{3}$, P Vital $^{3}$ and M A Cerbón ${ }^{2}$ \\ ${ }^{1}$ Instituto Nacional de Ciencias Médicas y Nutrición, SZ Vasco de Quiroga 15, Tlalpan 14000, D F México, México \\ ${ }^{2}$ Facultad de Química and ${ }^{3}$ Instituto de Fisiología Celular, Universidad Nacional Autónoma de México, Coyoacan 04510, D F México, México \\ (Requests for offprints should be addressed to S Morimoto, Departamento de Biología de la Reproducción, Instituto Nacional de Ciencias Médicas y \\ Nutrición, Salvador Zubirán, Vasco de Quiroga 15, Tlalpan 14000, DF México, México; Email sumimor@yahoo.com)
}

\begin{abstract}
Beta-cell apoptosis is responsible for the development of insulin-dependent diabetes mellitus in the streptozotocin (STZ) rat model. It has been demonstrated that steroid hormones possess antioxidant and protective antiapoptotic effects in many tissues. The aim of the present study was to investigate the early apoptotic damage induced by STZ in rat pancreas, and the effect of testosterone in preventing apoptosis of pancreatic $\beta$ cells. Intact and castrated adult male Wistar rats were subjected to a unique injection of STZ $60 \mathrm{mg} / \mathrm{kg}$ (body weight) in citrate buffer, and the kinetics of apoptosis in $\beta$ cells was assessed. Insulin and glucose were measured by RIA and a glucometer respectively, and in pancreatic tissue by immunohistochemistry. At $6 \mathrm{~h}$ after STZ injection, a marked increase in apoptotic $\beta$ cells was detected; however, glucose and insulin serum
\end{abstract}

levels were not significantly different from the controls. The castrated animals presented higher percentages of apoptotic $\beta$ cells $(65.75 \pm 5.42 \%)$ than intact males $(20 \cdot 6 \pm 4 \cdot 38 \%)$ and castrated, testosterone-substituted males $(30.66 \pm 1.38 \%)$. The decrease in apoptotic $\beta$ cells induced by testosterone was reversed by the antiandrogen flutamide $(67 \cdot 69 \pm 3 \cdot 45 \%)$. The overall results indicate that early apoptotic damage produced by STZ in castrated animals was reversed by testosterone, suggesting that this hormone exerts a natural protective effect in rat pancreas. This effect could help to explain some sexual differences in diabetes mellitus incidence in man, reinforcing the idea that new approaches in steroid hormone therapies should be considered for treatment of this disease.

Journal of Endocrinology (2005) 187, 217-224

\section{Introduction}

Streptozotocin (STZ) is an alkylating agent that produces $\beta$-cell death by the mechanism of DNA damage that induces poly-ADP-ribose synthetase activation, followed by lethal nicotinamide adenine dinucleotide (NAD) depletion, a mechanism well documented in rodent islets (Yang \& Wright 2002). During STZ metabolism, various toxic intermediates are produced, including methyl cations, methyl radicals, reactive oxygen species (ROS) and nitric oxide (NO) (Peschke et al. 2000, González et al. 2002). Beta cells are very susceptible to oxidative changes since they possess a low antioxidative capacity (Hotta et al. 1998, Kajimoto \& Kaneto 2004).

It is accepted that oxidative stress and apoptosis cause $\beta$-cell death in STZ-diabetic mice and nonobese diabetic (NOD) mice. NOD mice spontaneously develop autoimmune diabetes with remarkable similarity to human insulin-dependent diabetes mellitus (IDDM) (O’Brien et al. 1997). Injection of STZ induces progressive hyperglycemia, accompanied by lymphocytic infiltration of pancreatic islets. In some basic aspects, this model mimics recentonset IDDM in human patients (O'Brien et al. 1996).

There is evidence of sexual dimorphism in the incidence and prevalence of diabetes mellitus in animal models. In NOD mice, a greater incidence of diabetes in females $(70 \%)$ than in males $(15 \%)$ is found; this sexual dimorphism is related to the effects of sex steroid hormones (Baxter et al. 1989, Rosmalen et al. 2001).

The antioxidant properties of steroid hormones have been shown in different cells and tissues (Ahlbom et al. 2001, Aragno et al. 2002, Deroo et al. 2004, Miyake et al. 2004). For example, testosterone protects cerebellar granule cells from oxidative stress-induced cell death by a receptor-mediated mechanism (Ahlbom et al. 2001). In vivo, dehydroepiandrosterone (DHEA) exerts a multitargeted antioxidant activity in rats, protecting various organs against lipid peroxidation (Boccuzzi et al. 1997), and also prevents oxidative damage by hyperglycemia in rats (Aragno et al. 1997, Brignardello et al. 1998). Estradiol regulates several mechanisms that protect the mouse uterus against oxidative stress (Deroo et al. 2004). 
Several studies have shown that treatment with antioxidants reduces diabetic complications (Wohaieb \& Godin 1987, Siman \& Eriksson 1997, Aragno et al. 2002). These compounds attenuate the development of peripheral nerve dysfunction (Obrosova et al. 2002, Yorek et al. 2002), protect from diabetes-dependent brain damage (Aragno et al. 2002), normalize the endothelial function in diabetes (Ido et al. 1997, Haidara et al. 2004) and exert beneficial effects on platelet hyperaggregability (Ruf et al. 1992). Moreover, antioxidants decrease the occurrence of malformation in the offspring of diabetic rats (Viana et al. 1996, Siman \& Eriksson 1997).

The present study aimed to assess whether testosterone, the most abundant natural androgen in male rats, exerts a protective effect against the early apoptotic damage produced by STZ in pancreatic $\beta$ cells in vivo.

\section{Materials and Methods}

\section{Animals}

All animal maintenance and handling was in accordance with the guidelines of Mexican law on animal protection (NOM-062-ZOO-1999). Six groups of six male Wistar rats $(200-250 \mathrm{~g})$ each were formed: 1. intact; 2 . intact plus STZ; 3. intact plus flutamide plus STZ; 4. castrated plus STZ; 5. castrated plus testosterone enanthate plus STZ; 6 . castrated plus flutamide plus testosterone enanthate plus STZ. The animals were housed under controlled conditions of temperature and light: dark period (12:12 h). Glucose determinations were made with a drop of blood obtained by cutting the tail tip. The glucometer employed for determinations was Prestige Smart System (Home Diagnostics, Ft Lauderdale, FL, USA).

\section{Treatments}

Groups of rats were gonadectomized under ketaminexilazine anesthesia, a single, cutaneous incision was made through the scrotal sac and the peritoneal cavity was entered to expose the testes. The testicular bundles were ligated with 4-0 silk suture and the testes removed. The cutaneous incision was closed with 5-0 silk suture. At $72 \mathrm{~h}$ after gonadectomy, the animals received testosterone enanthate replacement therapy in a $200 \mathrm{mg} / \mathrm{kg}$ (body weight) single dose or vehicle (corn oil); $24 \mathrm{~h}$ after replacement, the animals were treated intraperitoneally with $60 \mathrm{mg} / \mathrm{kg}$ (body weight) STZ in citrate buffer $100 \mathrm{mM}, \mathrm{pH} 4 \cdot 5$, in a single dose, or citrate buffer as control. To confirm that the protective effect was mediated by the androgen receptor, the antiandrogen flutamide was tested. For this purpose, a group of castrated rats were substituted with testosterone enanthate similarly to the scheme described before, and treated with $100 \mathrm{mg} / \mathrm{kg}$ (body weight) of flutamide for 2 days, and then STZ was administered.

\section{Histology}

After $6 \mathrm{~h}$ of STZ treatment, the rats were killed and the pancreas was immersion-fixed in ice-cold $4 \%(\mathrm{w} / \mathrm{v})$ paraformaldehyde in PBS $(100 \mathrm{mM})$, overnight at $4{ }^{\circ} \mathrm{C}$. Tissues were dehydrated through a series of increasing ethanol concentrations $(25 \%, 50 \%, 70 \%, 80 \%, 96 \%$ and absolute) and finally cleared with xylene. Tissues were then embedded in Paraplast plus (Oxford Labware, St Louis, MO, USA). Tissue sections $(5 \mu \mathrm{m})$ were cut and mounted on poly-L-lysine-coated slides. Sections were cleared of paraplast with xylene, rehydrated and processed for the techniques detailed below.

\section{Double immunohistochemistry staining}

Paraffin sections were dewaxed, rehydrated, permeabilized and subsequently incubated overnight with guinea pig anti-porcine insulin antibody (1:4000) (Incstar, Stillwater, MN, USA), as recommended by the supplier's technical bulletins. Afterward, a second fluorescein isothiocyanate (FITC)-conjugated goat anti-guinea pig IgG antibody for insulin detection (1:100) (Jackson Immunoresearch Laboratories, Wets Grove, PA, USA). After this procedure, sections were incubated for $4 \mathrm{~h}$ with mouse anti-rat glucagon (1:6000) (Sigma) and a second CY5-conjugated goat anti-mouse $\operatorname{IgG}(1: 100)$ (Jackson Immunoresearch Laboratories).

Sections were observed by confocal microscopy with a BioRad MRC-1024 system, equipped with a $\mathrm{Kr} / \mathrm{Ar}$ laser attached to an inverted Nikon Diaphot TMD 300 microscope, with an oil-immersion,40 objective (Nikon Corporation, Tokyo, Japan). Iris aperture, gain and laser power remained fixed in each session, FITC was excited with a $494 \mathrm{~nm}$ wavelength, and emitted light was bandpassed with a $520 \mathrm{~nm}$ filter, while CY5 was excited with a $650 \mathrm{~nm}$ wavelength, and emitted light was bandpassed with a $670 \mathrm{~nm}$ filter.

The following controls were performed to achieve reliable double-immunostaining (data not shown):

1. Negative control of antibodies: experimental protocols were carried out without the addition of primary antisera or without the secondary antibody.

2. Controls of antisera specificity were performed with anti-insulin and anti-glucagon antibodies, preadsorbed overnight with their respective antigens and processed by the same protocol described above.

No fluorescent signal could be detected in either control. Confocal images were viewed and processed by Confocal Assistant 4.02 (Todd Clark, University of Minnesota, MN, USA).

Terminal deoxynucleotidyl transferase-mediated dUTP nick end labeling (TUNEL) assay

An in situ cell death detection kit (Roche) was used to visualize the apoptotic pancreatic cells. After being 
dewaxed through xylene and absolute ethanol, the slides were rehydrated through decreasing concentrations of ethanol and rinsed in PBS buffer saline. Rehydrated sections were incubated at room temperature for $30 \mathrm{~min}$ with proteinase $\mathrm{K}(20 \mu \mathrm{g} / \mathrm{ml}$ in $10 \mathrm{mM}$ Tris- $\mathrm{HCl}, \mathrm{pH}$ 8). After rinsing with PBS, sections were permeabilized with $0 \cdot 1 \%$ Triton X-100 in PBS for 2 min at $4{ }^{\circ} \mathrm{C}$. Positive control sections were treated for $10 \mathrm{~min}$ at $37^{\circ} \mathrm{C}$ with DNase. Slides were rinsed with PBS and incubated for $1 \mathrm{~h}$ at $37^{\circ} \mathrm{C}$ in the TUNEL reaction mixture (terminal deoxynucleotidyl transferase enzyme (TdT) with nucleotide-fluorescein-conjugated mixture in reaction buffer). In negative controls, TdT enzyme was omitted from the reaction mixture. The slides were rinsed in 0.01 M PBS buffer, $\mathrm{pH} 7 \cdot 4$, and mounted in fluorescent mounting medium (Dako, Carpinteria, CA, USA).

\section{Apoptotic nuclei analysis}

The slides were analyzed in an epi-fluorescence microscope, and the image of each preparation was acquired in an Axioscope 401 Zeiss system. The fluorescent nuclei were counted in at least 100 islets per animal and expressed as percentage of apoptotic nuclei with respect to the total nuclei in the pancreatic islets.

\section{Hormonal determinations}

The levels of testosterone, estradiol and insulin were assessed by specific RIA (Diagnostic Product Corporation, Los Angeles, CA, USA). The sensitivity of the assays was $5.43 \mathrm{pg} / \mathrm{ml}$ to estradiol, $2.47 \mathrm{pg} / \mathrm{ml}$ to testosterone and $0.05 \mathrm{ng} / \mathrm{ml}$ to insulin. The intra- and interassay coefficients of variation were $5 \cdot 3 \%$ and $8 \%, 4 \cdot 9 \%$ and $8 \cdot 2 \%$, and $3 \cdot 6 \%$ and $6 \%$ respectively.

\section{Statistical analysis}

All values reported are expressed as mean \pm S.E.M Differences between means were analyzed for significance by one-way ANOVA, followed by Tukey multiple comparison as post hoc test. The statistically significant value was $P<0 \cdot 05$.

\section{Results}

Time course of pancreatic damage by STZ

To establish the period of time in which the STZ damage was evident, we performed a kinetic analysis for different times: 1, 2, 3, 4, 6, 12 and $24 \mathrm{~h}$ in castrated male rats. During the first hour considered (1, 2, 3 and $4 \mathrm{~h}$ ), the apoptotic index was almost undetectable; however, a small number of islets presented scarce apoptotic nuclei (data not shown). At $6 \mathrm{~h}$, a marked increase in apoptotic $\beta$ cells was detected $(65 \cdot 75 \pm 5 \cdot 42 \%)$, although glucose levels were in normal range of $4 \cdot 6-5 \cdot 2 \mathrm{mmol} / \mathrm{l}$. In contrast, at 12 and $24 \mathrm{~h}$, the animals were hyperglycemic, $10 \cdot 6 \pm 0 \cdot 2$ and $26 \cdot 4 \pm 0.4 \mathrm{mmol} / 1$ respectively, and the apoptotic index was over $80 \%$ in both groups. Insulin concentration along time course of STZ administration (1, 2, 3, 4 and $6 \mathrm{~h}$ ) was normal $(1 \cdot 1-1 \cdot 7 \mathrm{ng} / \mathrm{ml})$, while at 12 and $24 \mathrm{~h}$ it was under $0.5 \mathrm{ng} / \mathrm{ml}$.

\section{Protective effect of testosterone in apoptotic-STZ produced damage}

The apoptosis of $\beta$ cells in pancreas was studied by the TUNEL method and observed by fluorescence microscopy. Fluorescent nuclei in pancreatic islets were counted and reported as percentage in relation to total nuclei (see Materials and Methods). As shown in Figs 1 and 2, STZ treatment induced a higher percentage of $\beta$-cell apoptosis in the castrated animals $(65 \cdot 75 \pm 5 \cdot 42 \%)$ than in intact males $(20 \cdot 6 \pm 4 \cdot 38 \%)$ and castrated, testosteronesubstituted males (30.66 $\pm 1 \cdot 38 \%)$. The decrease in apoptotic $\beta$ cells induced by testosterone was reversed by the antiandrogen flutamide, which reached similar values to those in castrated male animals $(67 \cdot 69 \pm 3 \cdot 45 \%)$. The apoptotic index observed in intact animals treated with flutamide was $64 \cdot 35 \pm 6 \cdot 35 \%$ (data not included in the figures). In addition, the apoptotic index was tested in intact animals in all experiments and was lower than $0 \cdot 5 \%$ in all cases (data not shown).

\section{Immunodetection of insulin and glucagon in pancreatic tissue}

Insulin and glucagon were assessed by double immunohistochemistry staining in slides of paraffin-embedded pancreatic tissue (Fig. 3). As expected, the insulin immunoreactive $\beta$ cells in the pancreas of all animals were localized in the core of pancreatic islets. Apoptosis was also detected in this area, which indicates that it is exhibited preferentially by $\beta$ cells. In contrast, glucagonpositive alpha cells were observed in the periphery of islets.

\section{Hormonal and glucose analysis}

Glucose levels in all animals are presented in Table 1. Interestingly, in all animals studied, the glucose levels were in the normal range.

To assess the hormonal status in intact, castrated and substituted animals, the levels of insulin, testosterone and estradiol were analyzed; the results are summarized in Table 2. As expected, testosterone values in castrated animals were almost undetectable; in contrast, substituted males presented increased testosterone values. Estradiol values were normal in all the groups. Insulin serum levels presented similar values in all experimental groups (Table 1). 

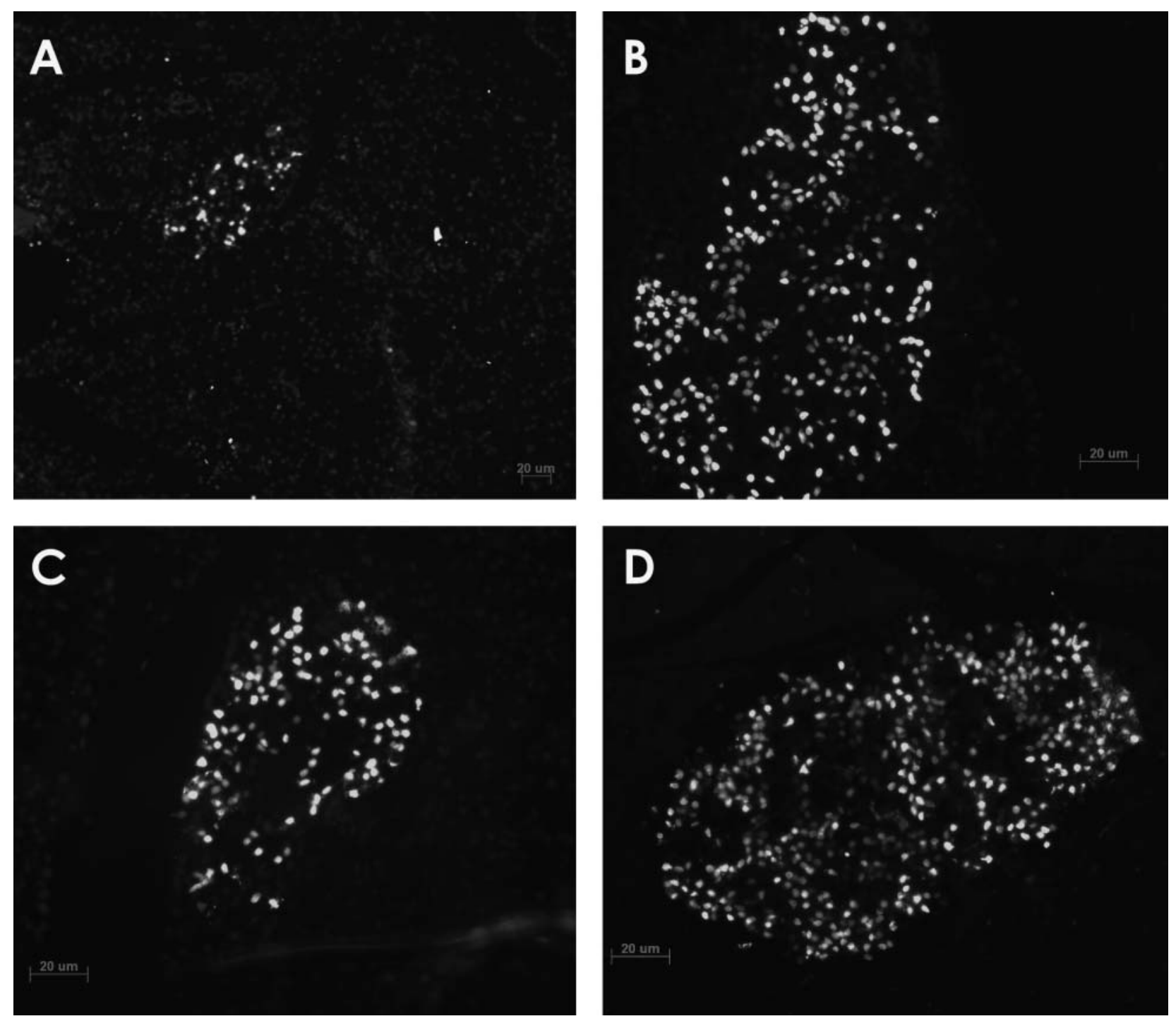

Figure 1 Apoptotic $\beta$ cells detected by terminal deoxynucleotidyl transferase-mediated dUTP nick end labeling (TUNEL) technique (see Materials and Methods) in pancreas slides from STZ-treated rats. Apoptotic nuclei in islets of Langerhans from intact male plus STZ (A), castrated male plus STZ (B), castrated plus testosterone plus STZ (C) and castrated plus testosterone plus flutamide plus STZ (D). Positive nuclei from cells were identified by fluorescent labeling. Bar $=20 \mu \mathrm{m}$ in all panels.

\section{Discussion}

In this study, we demonstrated the protective effect of testosterone in the early apoptotic damage induced by STZ to pancreatic $\beta$ cells. At $6 \mathrm{~h}$ after STZ administration to intact and castrated Wistar rats, pancreatic $\beta$-cell apoptosis without hyperglycemia was observed. We demonstrated that the presence of male gonads partially prevents $\beta$-cell apoptosis. Moreover, this result suggests that testosterone is involved in $\beta$-cell protection, since the administration of testosterone enanthate to castrated animals significantly reduced the apoptotic index, compared with castrated animals, and this effect was completely reversed by the androgen receptor antagonist flutamide, suggesting an androgen receptor-mediated mechanism.

STZ is widely used to produce experimental diabetes in rodents. This drug causes $\beta$-cell death by apoptosis and consequently diabetes (O'Brien et al. 1996). Our data demonstrate that STZ produced early apoptotic damage in pancreatic islets, producing higher apoptotic damage in castrated animals. Although a high apoptotic index was observed, it was not enough to produce hyperglycemia, because glucose levels in all the animals treated with STZ were in the normal range. These results agree with previous observations in similar experimental conditions of STZ administration at similar doses (Park et al. 1999). 


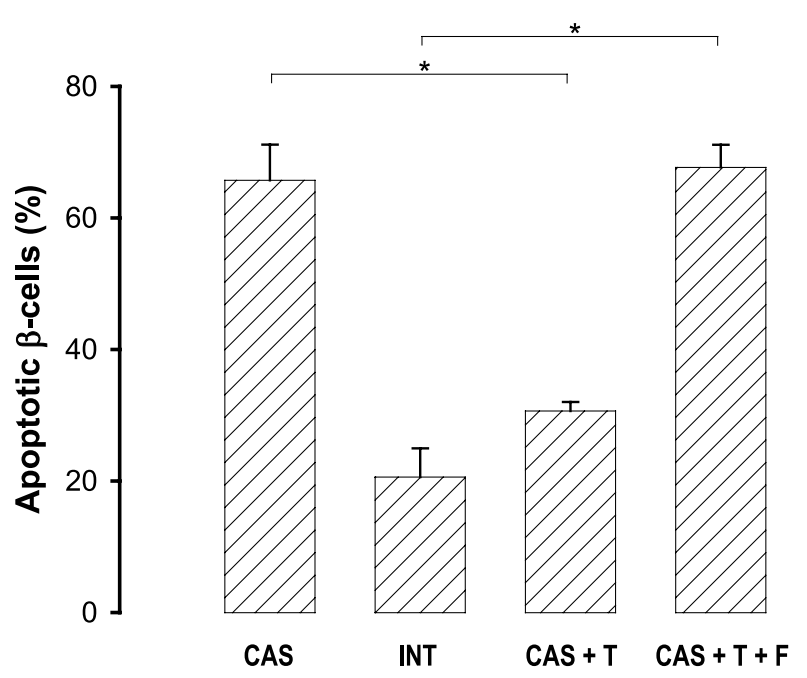

Figure 2 Apoptotic index in pancreatic islets in intact and treated animals. CAS: castrated rats treated with STZ; INT: intact rats treated with STZ; CAS+T: rats castrated and substituted with testosterone enanthate plus STZ; CAS+T+F: castrated rats treated with flutamide and substituted with testosterone enanthate plus STZ. Positive nuclei were counted in 100 islets per group and expressed as percentage of apoptotic nuclei with respect to the total nuclei in pancreatic islets. ${ }^{*} P<0.05$ between groups.

The authors demonstrated that $\beta$-cell alteration began $6 \mathrm{~h}$ after STZ injection. At this stage, many $\beta$ cells showed condensation of their nuclear chromatin, while the animals maintained their normal blood-glucose level (80$150 \mathrm{mg} / \mathrm{dl}$ ) for at least $12 \mathrm{~h}$ after STZ injection, followed by a steep glucose increase $(>300 \mathrm{mg} / \mathrm{dl})$ at $12-24 \mathrm{~h}$ after STZ injection.

The protection exhibited by testosterone against STZinduced apoptotic damage was more than $50 \%$, considering that apoptosis induced by STZ in castrated male was about $65.75 \%$ and in castrated substituted male was $30 \cdot 66 \%$. The apoptotic index observed in intact males was slightly lower than that observed in castrated/

Table 1 Glucose and insulin concentrations in the experimental groups

\begin{tabular}{|c|c|c|}
\hline & $\begin{array}{l}\text { Glucose } \\
(\mathrm{mmol} / \mathrm{L})\end{array}$ & $\begin{array}{l}\text { Insulin } \\
\text { (ng/ml) }\end{array}$ \\
\hline \multicolumn{3}{|l|}{ Animals } \\
\hline Intact & $5 \cdot 1 \pm 0 \cdot 7$ & $1 \cdot 2 \pm 0 \cdot 1$ \\
\hline Intact+STZ & $4 \cdot 9 \pm 0 \cdot 7$ & $1 \cdot 1 \pm 0 \cdot 7$ \\
\hline Intact+F+STZ & $5 \cdot 1 \pm 0 \cdot 6$ & $0 \cdot 8 \pm 0 \cdot 2^{a}$ \\
\hline Castrated+STZ & $4.9 \pm 0.6$ & $1 \cdot 7 \pm 0 \cdot 7^{\mathrm{b}}$ \\
\hline Castrated+T+STZ & $5 \cdot 2 \pm 0 \cdot 9$ & $1 \cdot 6 \pm 0 \cdot 5$ \\
\hline Castrated $+\mathrm{F}+\mathrm{T}+\mathrm{STZ}$ & $4 \cdot 6 \pm 0 \cdot 6$ & $1 \cdot 5 \pm 0 \cdot 4$ \\
\hline
\end{tabular}

Insulin and glucose levels in control and treated rats. STZ=streptozotocin; $\mathrm{T}=$ testosterone; $\mathrm{F}=$ flutamide. Data are shown as mean \pm S.E. $P<0 \cdot 01$ compared between ${ }^{\mathrm{a}}$ and ${ }^{\mathrm{b}}$. Three independent experiments were performed with $n=3-5$ per group.
Table 2 Testosterone and estradiol concentrations in experimental animals

\begin{tabular}{|c|c|c|}
\hline & $\begin{array}{l}\text { Testosteron } \\
(\mathrm{ng} / \mathrm{ml})\end{array}$ & $\begin{array}{l}\text { Estradiol } \\
(\mathrm{pg} / \mathrm{ml})\end{array}$ \\
\hline \multicolumn{3}{|l|}{ Animals } \\
\hline Intact & $1 \cdot 6 \pm 0 \cdot 20$ & $13 \cdot 64 \pm 1 \cdot 64^{a}$ \\
\hline Intact+STZ & $1 \cdot 7 \pm 0 \cdot 25$ & $12 \cdot 89 \pm 1 \cdot 5^{a}$ \\
\hline Intact+F+STZ & $1 \cdot 53 \pm 0.50$ & $15 \cdot 25 \pm 3 \cdot 0$ \\
\hline Castrated +STZ & $0 \cdot 2 \pm 0.05^{\mathrm{a}}$ & $15 \cdot 77 \pm 1 \cdot 70$ \\
\hline Castrated+T+STZ & $6 \cdot 3 \pm 1 \cdot 03^{b}$ & $17 \cdot 67 \pm 2 \cdot 0$ \\
\hline Castrated $+\mathrm{F}+\mathrm{T}+\mathrm{STZ}$ & $0 \cdot 2 \pm 0.015^{a}$ & $12 \cdot 01 \pm 1 \cdot 21^{\mathrm{a}}$ \\
\hline
\end{tabular}

Testosterone and estradiol serum levels, in intact and castrated male rats. $\mathrm{STZ}=$ streptozotocin; $\mathrm{T}=$ testosterone; $\mathrm{F}=$ flutamide. Data are shown as mean \pm S.E. ${ }^{a, b} P<0 \cdot 01$ compared with all animal groups.

testosterone treated animals, but not significantly different (Fig. 2). This could be due to the fact that in intact animals, in addition to testosterone, dihydrotestosterone (DHT) and other gonadal factors can also protect against STZ-induced apotosis (Fox 1992). This protection was similar to that observed in other steroid-protection models. In rat cerebellar granule neurons, testosterone decreased nitric oxide-induced apoptosis by $45 \%$ and hydrogen peroxide-induced apoptosis by 30\% (Ahlbom et al. 1999, 2001). In human primary neurons; testosterone decreased serum deprivation-mediated apoptosis by 20\% (Hammond et al. 2001). To our knowledge, the present study is the first to use testosterone to protect pancreatic $\beta$ cells against STZ-induced apoptosis.

Previous reports have indicated that the pancreatic islets can respond to androgens (Rosmalen et al. 2001). The administration of exogenous androgens is likely to prevent the effects of castration on glucose homeostasis, since it was shown in a multiple-dose STZ diabetes model that testosterone administered to control females or orchidectomized males results in a glucose response similar to that observed in control males (Rossini et al. 1978). It has also been reported that testosterone may protect against diabetes in the NOD model of type I diabetes, that female mice are more prone to diabetes development than males (Fitzpatrick et al. 1991) and that androgen treatment of NOD females reverses differences between the sexes (Fox 1992). In NOD mice, mega-islet formation is indicative of initial damage and the number of mega-islets is reduced by testosterone, as compared with controls (Rosmalen et al. 2001).

It is well recognized that steroids act through nuclear receptors that are ligand-regulated transcription factors and participate in many cellular process such as proliferation, differentiation and cell death (Altucci \& Gronemeyer 2001). Other mechanisms described for steroids in protection of cells against damage are related to their antioxidant properties via a membrane mechanism of action (Sotiriadou et al. 2003, Alexaki et al. 2004). Our data 

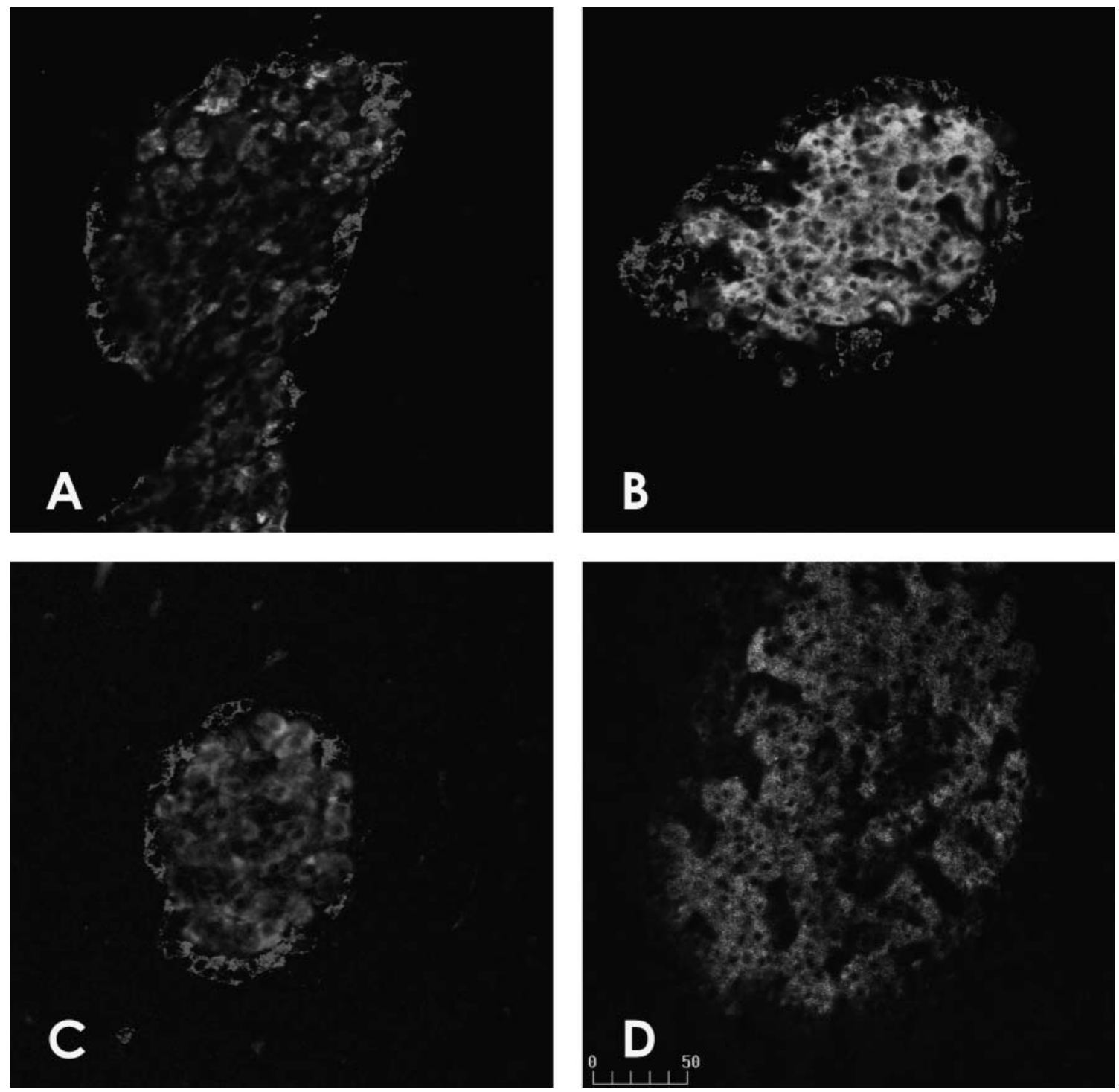

Figure 3 Double immunohistochemistry staining for insulin (core of islets) and glucagons (periphery of islets) in pancreas slides from STZ-treated male rats: intact plus STZ (A), castrated plus STZ (B), castrated plus testosterone plus STZ (C), castrated plus testosterone plus flutamide plus STZ (D). Bar $=50 \mu \mathrm{m}$ in all panels.

demonstrate that testosterone acts directly to protect $\beta$ cells against apoptotic damage produced by STZ. This effect could be mediated by the androgen receptor, since the androgen receptor antagonist flutamide completely abolished this effect. Activation of androgen receptors in this process is supported by previous observations demonstrating androgen receptor expression and regulation in rat pancreas (Díaz-Sánchez et al. 1995), and by the fact that testosterone increases insulin gene expression in rat islets in vitro (Morimoto et al. 2001a). Moreover, changes in insulin expression correlate well with changes in steroid hormone serum content during the estrous cycle (Morimoto et al. 2001b).
The cellular mechanism by which testosterone protects $\beta$ cells against early apoptotic damage in STZ-treated rats has not been fully established. However, there exist some possibilities. The main effectors in STZ damage are free radicals, such as reactive oxygen species (ROS) and nitric oxide (NO) (Peschke et al. 2000, González et al. 2002). Androgens modulate enzymes that help cells to escape this type of damage (Ahlbom et al. 1999, 2001, Aragno et al. 1999). In rat ventral prostate, testosterone regulates a set of oxidative stress-related genes, including thioredoxin, peroxiredoxin 5 , superoxide dismutase 2 , glutathione peroxidase 1, selenoprotein $15 \mathrm{kDa}$, microsomal glutathione$S$-transferase, glutathione reductase and epoxide hydrolase 
(Pang et al. 2002, Tam et al. 2003), and inhibits cell death by controlling caspase- 3 and -6 mRNA levels as well as procaspase and active caspase- 3 and -6 proteins levels (Omezzine et al. 2003). Further investigation is required to determine whether those processes are involved in the protection of pancreatic $\beta$ cells by testosterone, and investigation of this possible mechanism is in progress in our laboratory.

The overall results suggest that steroids hormones exert some natural protective effects in rat pancreas and could help to explain some sex differences in diabetes mellitus in man, reinforcing the idea that new approaches in steroid hormone therapies should be considered for treatment of this disease.

\section{Acknowledgements}

This work was supported in part by PAPIIT IN210605-2 and Facultad de Química grant PAIP 6190-08, Universidad Nacional Autónoma de México, México. The authors declare that there is no conflict of interest that would prejudice the impartiality of this scientific work.

\section{References}

Ahlbom E, Grandison L, Bonfoco E, Zhivotovsky B \& Ceccatelli S 1999 Androgen treatment of neonatal rats decreases susceptibility of cerebellar granule neurons to oxidative stress in vitro. European Journal of Neurosciences 11 1285-1291.

Ahlbom E, Prins GS \& Ceccatelli S 2001 Testosterone protects cerebellar granule cells from oxidative stress-induced cell death through a receptor mediated mechanism. Brain Research $\mathbf{2 3}$ 255-262.

Alexaki VI, Charalampopoulos I, Kampa M, Vassalou H, Theodoropoulos P, Stathopoulos EN, Hatzoglou A, Gravanis A \& Castanas E 2004 Estrogen exerts neuroprotective effects via membrane estrogen receptors and rapid Akt/NOS activation. FASEB Journal 18 1594-1596.

Altucci L \& Gronemeyer H 2001 Nuclear receptors in cell life and death. Trends in Endocrinology and Metabolism 12 460-468.

Aragno M, Brignardello E, Tamagno E, Gatto V, Danni O \& Boccuzzi G 1997 Dehydroepiandrosterone administration prevents the oxidative damage induced by acute hyperglycemia in rats. Journal of Endocrinology 155 233-240.

Aragno M, Tamagno E, Gatto V, Brignardello E, Parola S, Danni O \& Boccuzzi G 1999 Dehydroepiandrosterone protects tissues of streptozotocin-treated rats against oxidative stress. Free Radical Biology and Medicine 26 1467-1474.

Aragno M, Mastrocola R, Brignardello E, Catalano M, Robino G, Manti R, Parola M, Danni O \& Boccuzzi G 2002 Dehydroepiandrosterone modulates nuclear factor-kappaB activation in hippocampus of diabetic rats. Endocrinology 143 3250-3258.

Baxter AG, Adams MA \& Mandel TE 1989 Comparison of high- and low-diabetes-incidence NOD mouse strains. Diabetes 38 1296-1300.

Boccuzzi G, Aragno M, Seccia M, Brignardello E, Tamagno E, Albano E, Danni O \& Bellomo G 1997 Protective effect of dehydroepiandrosterone against copper-induced lipid peroxidation in the rat. Free Radical Biology and Medicine 22 1289-1294.

Brignardello E, Beltramo E, Molinatti PA, Aragno M, Gatto V, Tamagno E, Danni O, Porta M \& Boccuzzi G 1998
Dehydroepiandrosterone protects bovine retinal capillary pericytes against glucose toxicity. Journal of Endocrinology 158 21-26.

Deroo BJ, Hewitt SC, Peddada SD \& Korach KS 2004 Estradiol regulates the thioredoxin antioxidant system in the mouse uterus. Endocrinology 145 5485-5492.

Díaz-Sánchez V, Morimoto S, Morales A, Robles-Díaz G \& Cerbón MA 1995 Androgen receptor in the rat pancreas: genetic expression and steroid regulation. Pancreas 11 241-245.

Fitzpatrick F, Lepault F, Homo-Delarche F, Bach JF \& Dardenne M 1991 Influence of castration, alone or combined with thymectomy, on the development of diabetes in the nonobese diabetic mouse. Endocrinology 129 1382-1390.

Fox HS 1992 Androgen treatment prevents diabetes in nonobese diabetic mice. Journal of Experimental Medicine 175 1409-1412.

Gavrieli Y, Sherman Y \& Ben-Sasson SA 1992 Identification of programmed cell death in situ via specific labeling of nuclear DNA fragmentation. Journal of Cell Biology 119 493-501.

González E, Jawerbaum A, Sinner D, Pustovrh, White V, Capobianco E, Xaus C, Peralta C \& Roselló-Catafau J 2002 Streptozotocinpancreatic damage in the rat: modulatory effect of 15-deoxy delta12,14-prostaglandin $\mathrm{j}(2)$ on nitridergic and prostanoid pathway. Nitric Oxide 6 214-220.

Haidara MA, Khloussy H, Ammar H \& Aal Kassem LA 2004 Impact of alpha-tocopherol and vitamin $\mathrm{C}$ on endothelial markers in rats with streptozotocin-induced diabetes. Medical Science Monitor $\mathbf{1 0}$ BR 41-46.

Hammond J, Le Q, Goodyer C, Gelfand M, Trifiro M \& LeBlanc A 2001 Testosterone-mediated neuroprotection through the androgen receptor in human primary neurons. Journal of Neurochemistry $\mathbf{7 7}$ 1319-1326.

Hotta M, Tashiro F, Ikegami H, Niwa H, Ogihara T, Yodoi J \& Miyazaki J 1998 Pancreatic beta cell-specific expression of thioredoxin, an antioxidative and antiapoptotic protein, prevents autoimmune and streptozotocin-induced diabetes. Journal of Experimental Medicine 188 1445-1451.

Ido Y, Kilo C \& Williamson JR 1997 Cytosolic NADH/NAD ${ }^{+}$, free radicals, and vascular dysfunction in early diabetes mellitus. Diabetologia 40 Suppl 2 S115-117.

Kajimoto Y \& Kaneto H 2004 Role of oxidative stress in pancreatic beta-cell dysfunction. Annals of the New York Academy of Sciences 1011 168-176.

Miyake H, Hara I, Gleave ME \& Eto H 2004 Protection of androgen-dependent human prostate cancer cells from oxidative stress-induced DNA damage by overexpression of clusterin and its modulation by androgen. Prostate 61 318-323.

Morimoto S, Fernández-Mejía C, Romero-Navarro G, Morales-Peza N \& Díaz-Sánchez V 2001a Testosterone effect on insulin content, messenger ribonucleic acid levels, promoter activity and secretion in the rat. Endocrinology 142 1442-1447.

Morimoto S, Cerbón MA, Alvarez-Alvarez A, Romero-Navarro G \& Díaz-Sánchez V $2001 b$ Insulin gene expression pattern in rat pancreas during the estrous cycle. Life Sciences 68 2979-2985.

O’Brien BA, Harmon BV, Cameron DP \& Allan DJ 1996 Beta-cell apoptosis is responsible for the development of IDDM in the multiple low-dose streptozotocin model. Journal of Pathology 178 176-181.

O’Brien BA, Harmon BV, Cameron DP \& Allan DJ 1997 Apoptosis is the mode of beta-cell death responsible for the development of IDDM in the nonobese diabetic (NOD) mouse. Diabetes 46 750-757.

Obrosova IG, Van Huysen C, Fathallah L, Cao XC, Greene DA \& Stevens MJ 2002 An aldose reductase inhibitor reverses early diabetes-induced changes in peripheral nerve function, metabolism, and antioxidative defense. FASEB Journal 6 123-125.

Omezzine A, Mauduit C, Tabone E, Nabli N, Bouslama A \& Benahmed M 2003 Caspase- 3 and -6 expression and activation are targeted by hormone action in the rat ventral prostate during the apoptotic cell death process. Biology of Reproduction 69 752-760. 
Pang ST, Dillner K, Wu X, Pousette A, Norstedt G \& Flores-Morales A 2002 Gene expression profiling of androgen deficiency predicts a pathway of prostate apoptosis that involves genes related to oxidative stress. Endocrinology 143 4897-4906.

Park IS, Che YZ, Bendayan M, Kang SW \& Min BH 1999 Up-regulation of clusterin (sulfated glycoprotein-2) in pancreatic cells upon streptozotocin injection to rats. Journal of Endocrinology $16257-65$.

Peschke E, Ebelt H, Brömme HJ \& Peschke D 2000 'Classical' and 'new' diabetogens - comparison of their effects on isolated rat pancreatic islets in vitro. Cellular and Molecular Life Sciences $\mathbf{5 7}$ 158-164.

Pushkala K \& Gupta PD 2001 Steroid hormones regulate programmed cell death: a review. Cytobios 106 201-217.

Rosmalen JGM, Pigmans MJG, Kerseboom R, Dreshage HA, Leenen PJM \& Homo-Delarche F 2001 Sex steroids influence pancreatic islet hypertrophy and subsequent autoimmune infiltration in nonobese diabetic (NOD) and NOD scid mice. Laboratory Investigation 81 231-239.

Rossini AA, Williams RM, Appel MC \& Like AA 1978 Sex differences in the multiple-dose streptozotocin model of diabetes. Endocrinology 103 1518-1520.

Ruf JC, Ciavatti M, Gustafsson T \& Renaud S 1992 Effect of D-myo-inositol on platelet function and composition and on cataract development in streptozotocin-induced diabetic rats. Biochemical Medicine and Metabolic Biology 48 46-55.

Siman CM \& Eriksson UJ 1997 Vitamin E decreases the occurrence of malformations in the offspring of diabetic rats. Diabetes 46 1054-1061.
Sotiriadou S, Kyparos A, Mougios V, Trontzos Ch, Sidiras G \& Matziari Ch 2003 Estrogen effect on some enzymes in female rats after downhill running. Physiological Research 52 743-748.

Tam NNC, Gao Y, Leung YK \& Ho SM 2003 Androgenic regulation of oxidative stress in the rat prostate. Involvement of $\mathrm{NAD}(\mathrm{P}) \mathrm{H}$ oxidases and antioxidant defense machinery during prostatic involution and regrowth. American Journal of Pathology 163 2513-2522.

Viana M, Herrera E \& Bonet B 1996 Teratogenic effects of diabetes mellitus in the rat. Prevention by vitamin E. Diabetologia 39 1041-1046.

Wohaieb SA \& Godin DV 1987 Alterations in free radical tissue-defense mechanisms in streptozocin-induced diabetes in rat. Effects of insulin treatment. Diabetes 36 1014-1018.

Yang H \& Wright JR 2002 Human beta cells are exceedingly resistant to streptozotocin in vivo. Endocrinology 143 2491-2495.

Yorek MA, Coppey LJ, Gellett JS, Davidson EP, Bing X, Lund DD \& Dillon JS 2002 Effect of treatment of diabetic rats with dehydroepiandrosterone on vascular and neural function. American Journal of Physiology - Endocrinology and Metabolism 283 E1067-E1075.

Received 26 May 2005

Accepted 5 August 2005

Made available online as an

Accepted Preprint 23 August 2005 